\title{
Determinants of Firm Value and Profitability: Evidence from Indonesia
}

\author{
Bambang SUDIYATNO ${ }^{1}$, Elen PUSPITASARI ${ }^{2}$, Titiek SUWARTI ${ }^{3}$, Maulana Muhammad ASYIF ${ }^{4}$ \\ Received: August 01, 2020 Revised: September 30, 2020 Accepted: October 15, 2020
}

\begin{abstract}
The purpose of this study was to examine the role of profitability as a mediating variable in influencing firm value. This study uses a sample of manufacturing companies listed on the Indonesia Stock Exchange from 2016 to 2018. The data used is panel data, with data analysis using multiple regression. Based on the Sobel test, profitability plays a role in mediating the effect of firm size on firm value. The effect of firm size on firm value is indirect, however, through profitability. Therefore, the market price of the shares of large-scale companies will increase if the resulting profitability is high. The capital structure and managerial ownership directly influence firm value. The results showed that managerial ownership and firm size had a positive effect on profitability, while capital structure had no effect on profitability. Capital structure and managerial ownership have a negative effect on firm value, while firm size and profitability have a positive effect on firm value. The main finding of this study is that profitability acts as an intervening variable in mediating the relationship between firm size and firm value.
\end{abstract}

Keywords: Firm Size, Capital Structure, Managerial Ownership, Profitability, Firm Value

JEL Classification Code: G31, G34, J52, O16

\section{Introduction}

The growth rate of shares of manufacturing companies listed on the Indonesia Stock Exchange has been fluctuating over the past five years due to the continuous development of the global economy. With these fluctuations, the share price as a representation of the firm's performance and firm value is a major concern among shareholders. This concern is very reasonable, considering that till the end of 2019 the global

${ }^{1}$ First Author and Corresponding Author. Associate Professor, Department of Management, Faculty of Economics and Business, Universitas Stikubank, Indonesia [Postal Address: Jl. Kendeng V Bendan Ngisor, Sampangan, Semarang, Central Java, 50233, Indonesia] E-mail: bsud@edu.unisbank.ac.id

${ }^{2}$ Lecture, Department of Accounting, Faculty of Economics and Business, Universitas Stikubank, Indonesia.

Email: elenpuspita@edu.unisbank.ac.id

${ }^{3}$ Lecture, Department of Accounting, Faculty of Economics and Business, Universitas Stikubank, Indonesia.

Email: titiek_s@edu.unisbank.ac.id

${ }^{4}$ Research Scholar, Department of Management, Faculty of Economics and Business, Universitas Stikubank, Indonesia.

Email: maulana.asyif@gmail.com

(c) Copyright: The Author(s)

This is an Open Access article distributed under the terms of the Creative Commons Attribution Non-Commercial License (https://creativecommons.org/licenses/by-nc/4.0/) which permits unrestricted non-commercial use, distribution, and reproduction in any medium, provided the original work is properly cited. economy had not shown signs of improvement. The trade war between China and the United States as two superpowers in the economic field has significantly weakened the global economy and there is considerable uncertainty regarding the global economic outlook.

Some stock market prices on the Indonesia Stock Exchange based on closing prices have increased and decreased. TOTO's share price had fallen from IDR 396.66 at the end of 2014 to IDR 348.00 at the end of 2018 . The price of BATA shares had also fallen from IDR 1,105.00 at the end of 2014 to IDR 600.00 at the end of 2018. Furthermore, the price of ULTJ shares increased from IDR 930.00 at the end of 2014 to IDR 1,350.00 at the end of 2018. The market price of a share is the price per share that investors are willing to pay, and this price reflects the market value of the company; therefore, the changes in share market prices indicate changes in firm value.

Information on share market price developments can help investors in determining their investment policies. The share market price which is a representation of firm value, its development will determine firm value and will be able to influence investors' investment-making decisions. One indicator of firm value can be proxy by using Price to Book Value (PBV), which is a comparison between the market price of a company's shares with the book value of the company's shares. By looking at the Price to Book 
Value (PBV), investors can find out the value of their shares whether it is undervalued or overvalued. Investors will buy shares if the value of the share is undervalued, and will not buy shares that are overvalued.

In previous studies related to factors that influence firm value, different results with different views of authors have been obtained. A study conducted by Murni (2015) found that profitability has a negative effect on firm value, while Arifianto and Chabachib (2016) found that profitability has a positive effect on firm value. A study conducted by Chen and Chen (2011) found that leverage has a negative effect on firm value, while results from the study conducted by Khrisnan and Charumathi (2016), found that leverage has a positive effect on firm value. Furthermore, the results of the study conducted by Arifianto and Chabachib (2016), found that the size of the firm has a positive effect on firm value, while a study conducted by Hirdinis (2019), indicates that the size of the firm has a negative effect on firm value.

Based on the results of the previous studies, which are not consistent with the factors that influence firm value, this research considers profitability as an intervening variable in influencing firm value. This is due to the possibility that the inconsistency was caused due to direct and indirect effects on firm value. Therefore, this study is to investigate the role of profitability variables in influencing firm value.

\section{Literature Review}

This study refers to the results of previous studies based on established financial theories, namely trade-off theory, pecking order theory, agency theory, and signaling theory.

\subsection{Trade-Off Theory}

The trade-off theory was initiated by Kraus and Litzenberger (1973) and later developed by Myers and Majluf (1984) and subsequent studies. The development of the tradeoff theory aims to counter the proposition of Modigliani and Miller (1958), because in many cases the benefits of using debt are zero or negative, assuming no corporate taxes (Dinh \& Pham, 2020). Modigliani and Miller (1963) developed the Modigliani-Miller Irrelevance Theorem (MMT). They later published their research in a 1958 paper entitled 'The Cost of Capital, Corporate Finance and the Theory of Investment' in the America Economic Review. This paper was later supplemented and partially corrected in a 1963 follow-up paper entitled 'Corporate Income Taxes and the Cost of Capital: A Correction'. The central premise of the MMT is that the value of a company is independent of its capital structure. Whether a company is capitalized with debt or equity provided certain assumptions are met (no taxes, no transaction, bankruptcy, or agency costs; no asymmetrical information; and the presence of efficient markets). This correction is a refinement of the previous MMT model, with changes in assumptions that take into account corporate taxes. Ehrhardt and Brigham (2011) developed another model is known as the MM-2 model or the MM model with corporate taxes.

According to the trade-off theory, companies will use debt to a certain level, where tax shields from additional debt equal the cost of financial distress. The cost of financial distress is the cost of bankruptcy or re-organization and agency costs that increase as a result of the decline in the company's credibility. Trade-off theory in determining the optimal capital structure includes several factors, including taxes, agency cost, and the cost of financial distress; however, it still maintains the assumption of market efficiency and symmetric information as a balance and the benefits of using debt. The optimal debt level is reached when the tax savings reach the maximum amount, which is equal to the cost of bankruptcy.

\subsection{Pecking Order Theory}

Pecking order theory was introduced by Donalson in 1961, but the naming of the Pecking Order Theory was done by Myers and Majluf (1984). Pecking order theory explains why companies with higher profitability have smaller debts. Specifically, companies have a sequence of preferences in the use of funds, starting from low-cost funds to high-cost funds. Financing comes from three sources, internal funds, debt, and new equity. Companies prioritize their sources of financing, first preferring internal financing, and then debt, lastly raising equity as a last resort.

The choice of internal funding sources (internal equity) according to Donaldson (1961), is because the company wants to avoid floatation costs that usually come with external funding, and this statement is supported by Myers and Majluf (1984). They stated that companies prioritize their sources of financing (from internal financing to equity) according to the cost of financing, preferring to raise equity as a financing means of last resort. They stated that although the net benefits from financing obtained through the use of external financing sources are likely to be greater than the floatation cost, the use of internal funding sources is to maximize the wealth of current shareholders. For instance, the sale of new shares may not be attractive to current shareholders where the sale of new shares can lead to a decline in the market price of the company's shares. However, in reality, some companies meet their sources of financing that may not be as per the sequence scenario mentioned in the pecking order theory.

\subsection{Agency Theory}

Agency theory describes the relationship between shareholders as principals and management as agents. An agency is any relationship between two parties in which one, the agent, represents the other, the principal, in day-to-day 
transactions. The principals have hired the agent to perform a service on their behalf. Agency theory was developed by Jensen and Meckling (1976), they explain agency relationship "as a contract under which one or more person (the principals) engage another person (the agent) to perform some services on their behalf which includes delegating some decision-making authority to the agent".

As explained earlier, the company's main goal is to increase the value of the company. To achieve this goal, the shareholders as the owner of the company (principal) appoint managers as agents to run the company in accordance with the interests of the owner, namely to improve their welfare by increasing the firm value. However, in practice, the manager often has other objectives that sometimes conflict with the main goal, such that it often creates a conflict of interest between the manager as an agent and the owner as the principal, and this conflict is known as agency conflict.

In this theory, management who acts as an agent tends to obtain maximum profits. Because many decisions that affect the principals financially are made by the agent, differences of opinion, and even differences in priorities and interests, can arise. Agency problems will occur if the proportion of managerial ownership of company shares is less than $100 \%$, so managers tend to act to pursue their own interests, and do not base on maximizing the value of the company while making decisions, especially funding decisions.

\subsection{Signaling Theory}

Research on the value of the company has been done, where most of the research is related to factors that influence the firm value. There are many factors that affect the firm value, both internal and external factors. These factors can directly or indirectly affect the firm value, including debt policy, asset structure, firm size, liquidity, profitability, free cash flow, ownership structure, interest rates, inflation, and others. However, this research will only examine the variables of profitability, capital structure, managerial ownership, and firm size, by placing profitability as an intervening variable in influencing firm value.

The results of the study conducted by Manurung et al. (2014) and Rizki et al. (2018), showed that capital structure has a negative effect on profitability. Lusy et al. (2018) found that capital structure has a positive effect on profitability, while Alpi (2018) found that capital structure has no effect on profitability. The results of this study show that companies with high profitability tend to have little debt, while companies that have low profitability have a lot of debt.

The results of the study conducted by Laila et al. (2017), found that managerial ownership negatively affected profitability. While research from Hossain (2016) showed that managerial ownership has no effect on profitability. The results of the study show empirical evidence that management involvement as the owner does not have a positive impact on profitability. This is likely to occur, because the proportion of management ownership is relatively small, less than $5 \%$, compared to the ownership of institutions that own a larger share of the company.

Firm size is a size, scale or variable that describes the size of the company based on several factors, including total assets, market value, total sales, total revenue, total capital and others. Meanwhile, according to Brigham and Houston (2015), firm size is the average of total net sales for the year up to several years. In this case, where sales are greater than variable costs and fixed costs, the amount of income before tax will be obtained. Firm size can affect company performance, because large-scale companies have broader views and opportunities to use their resources, making it easier to adapt to their environment.

Large-scale company managers will be more flexible in managing and developing their resources, especially in terms of business expansion. Therefore, large-scale companies tend to have greater opportunities to generate profits compared to small-scale companies. Large profits will increase profitability if it is generated from effective and efficient asset management. A study on the effect of firm size on profitability conducted by Laila et al. (2017) and Hirdinis (2019), found that firm size has a positive effect on profitability. However, the results of the study conducted by Hossain (2016) found a different thing, namely firm size does not affect profitability.

The results of the study regarding capital structure, managerial ownership, firm size, profitability, and firm value were carried out by Chen and Chen (2011) and Manurung et al. (2014), found that capital structure negatively affects the firm value. However, the results of the study conducted by Charumathi and Khrisnan (2016), Adenugba et al (2016), and Hirdinis (2019) found that capital structure has a positive effect on firm value. The results of the study conducted by Setiadharma and Machali (2017), and Purba and Africa (2019) found that capital structure does not affect firm value.

The results of the study show empirical evidence that the effect of the use of debt results in a different effect on the company's stock market price. This is due to the company's internal conditions that are not the same, therefore, different investors respond differently to the company's policy of using debt as a source of financing. In this case, investors' confidence in the company is very important, because the use of debt concerns the company's credibility. Investors will trust and invest their funds in the company if the company can manage its debt maximally to make a profit. Therefore, investors will respond by buying the company shares at a higher price; this impact will increase the firm value. Therefore, the debt policy will increase the value of the company, and vice versa if there is no investor confidence in the company. 
Managers must adopt the best business policies to improve shareholder welfare. However, shareholders cannot oversee all policies and activities carried out by managers, so the policies will likely be aimed at the manager's interests and harm shareholders. Therefore, to ensure that the policy does not harm shareholders, managers need to be given a portion of share ownership so that their position becomes equal. Debt use policy has an impact on increasing debt and will be able to reduce agency conflicts and excess cash flow within the company, thereby reducing agency costs. With the debt, the company must make periodic payments for the payment of interest and principal, so that it can reduce the desire of managers to use free cash flow to finance activities that are not optimal (Jensen, 1986).

The results of the study conducted by Murni (2015) and Indrarini et al. (2019), found that managerial ownership has a negative effect on firm value. However, the study conducted by Fajri and Surjandari (2016), and Purba and Africa (2019) did not find any effect of manager ownership on firm value. The results of the study show empirical evidence that the involvement of managers in share ownership has not been able to increase the share's market price. It is possible that managerial ownership does not directly affect the firm value, as such, investors do not respond directly to managerial ownership while making investment decisions since the amount of managerial ownership is relatively small.
Therefore, the possibility is an indirect effect, namely through other variables, such as profitability.

Firm size becomes an important part to increase the firm value because large-scale companies get more trust from investors. Managers must continue to step on uncertain terrain, adopt policies, and tighten projected revenues and costs to ensure the health of the company in the long run. Managers must take strategic steps to increase business growth, namely seeking funds from investors to accelerate growth and reach new levels of profit. Thus, the manager must be able to package ideas to attract and convince investors of the company's potential.

The results of the study conducted by Arifianto and Chabachib (2016) found that firm size has a positive effect on firm value. The results of this study differ from the results of the study conducted by Hirdinis (2019) who found that firm size had a negative effect on firm value. The results of the study conducted by Setiadharma and Machali (2017) also yielded a different finding, namely that the size of the company does not affect firm value. The results of the study show empirical evidence that there is a lack of clarity about the effect of the company's size on firm value. This lack of clarity is likely due to the behavior of investors who assume that large-scale companies do not guarantee investment will provide a large return as well, and this concerns investor confidence.

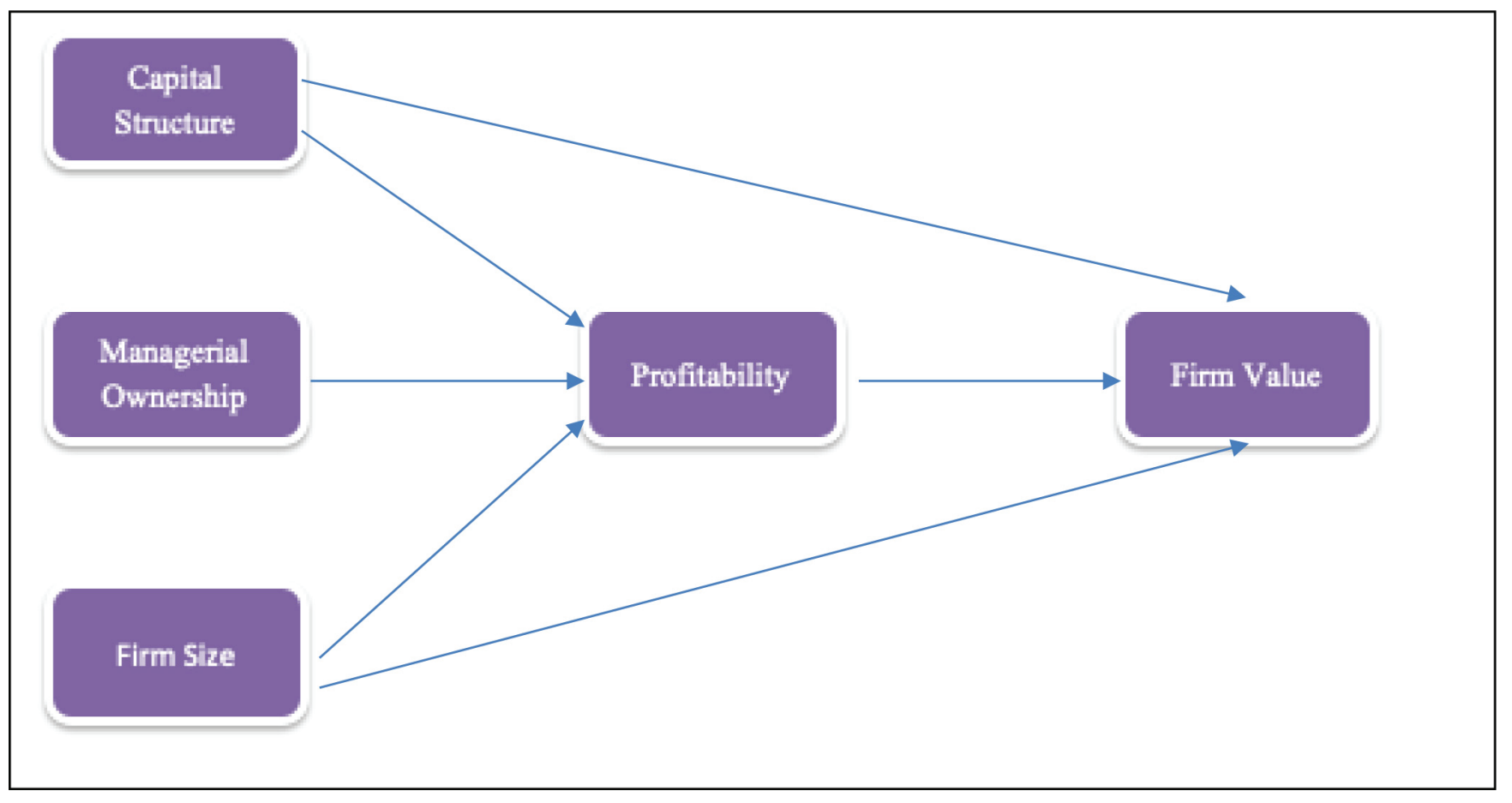

Figure 1: Empirical Research Model 
The results of the study regarding profitability and firm value conducted by Manurung et al. (2014), Arifianto and Chabachib (2016), and Purba and Africa (2019) found that profitability had a positive effect on firm value. However, it is different from the results of Murni (2015), who found that profitability had a negative effect on firm value. The results of the study conducted by Fajri and Surjandari (2016) and Hirdinis (2019) found that profitability does not affect firm value. The results of the study show empirical evidence that investors do not always consider profitability as an indicator of the firm's performance and for deciding their investment.

Hence, this study examined the role of profitability as a mediating variable in influencing firm value. The empirical research model is shown in Figure 1. The investigation is based on the following hypotheses:

H1a: Capital structure significantly and positively affects profitability.

H1b: Capital structure significantly and positively affects firm value.

H2a: Managerial ownership significantly and positively affects profitability.

H2b: Managerial ownership significantly and positively affects firm value.

H3a: Firm size significantly and positively affects profitability.

H3b: Firm size significantly and positively affects the firm value.

H4a: Profitability mediates the effect of capital structure on firm value.

H4b: Profitability mediates the effect of managerial ownership on firm value.

H4c: Profitability mediates the effect of firm size on firm value.

\section{Research Methods}

\subsection{Data}

The data analysis in this study uses the financial data of manufacturing companies listed on the Indonesia Stock Exchange (IDX) from 2016 to 2018 . The sample selection used the purposive sampling method and obtained 184 samples $(\mathrm{N})$. The variables in this research are profitability (ROE), firm value (PBV), capital structure (DER), managerial ownership (percentage of share ownership), and firm size (Ln Total Assets).

\subsection{Data Analysis}

The data analysis technique used is multiple linear regression analysis, and mediation test using the Sobel test. Data analysis was performed using 2 (two) models of multiple regression equations. Regression Equation 1 is as follows:

$$
\text { Proft }=a_{11}+b_{11} C S+b_{12} \mathrm{MO}+b_{13} \text { Size }+e_{1}
$$

Regression Equation 2 is as follows:

$$
\mathrm{FV}=\mathrm{a}_{22}+\mathrm{b}_{21} \mathrm{CS}+\mathrm{b}_{22} \mathrm{MO}+\mathrm{b}_{23} \text { Size }+\mathrm{b}_{24} \text { Proft }+\mathrm{e}_{22}
$$

Where:

Proft $=$ Profitability

$\mathrm{FV}=$ Firm Value

$\mathrm{CS}=$ Capital Structure

$\mathrm{MO}=$ Managerial Ownership

Size $=$ Firm Size

\subsection{Sobel Test}

To test how big the role of profitability is in mediating the effect of capital structure, managerial ownership, and firm size on firm value, the Sobel test is used. Where the Sobel test uses the $\mathrm{Z}$ test with the following formulation:

$$
\left.Z=a b / \sqrt{\left(b^{2}\right)} S E a^{2}\right)+\left(a^{2} S E b^{2}\right)
$$

Where :

$a=$ Regression coefficient of the independent variable to intervening variables.

$b=$ Regression coefficient of the intervening variable to the dependent variable.

$\mathrm{SEa}=$ Standard error estimation of the independent effect on the intervening variable.

$\mathrm{SEb}=$ Standard error estimation of the effect of direct variables intervening with the dependent variable.

In this study, intervening variables (profitability) can be said to mediate the effect of $X$ (capital structure, managerial ownership, and firm size) on Y (firm value) if the value of $\mathrm{Z}>1.96$.

\section{Results and Discussion}

\subsection{Descriptive Statistics}

Based on the observation of 126 samples, the value of the company in $2016-2018$ ranged from $17 \%$ to $410 \%$, with an average value of $107.44 \%$ and a standard deviation of $79.66 \%$. Likewise, profitability ranges from $0.00 \%$ to $32 \%$, with an average value of $8.81 \%$ and a standard deviation of $6.65 \%$. Capital structure ranges from $11 \%$ to $527 \%$, with an average value of $95.95 \%$ and a standard deviation of $89.91 \%$. Managerial ownership ranges from $0.00 \%$ to $89 \%$, with a standard deviation of 21.04 . Firm size ranges from $1185 \%$ to $2391 \%$, with an average value of $1474.70 \%$ and a standard deviation of $2072.51 \%$. 
When viewed from the profitability of the company, the average profitability generated by the manufacturing companies listed on the Indonesia Stock Exchange during 2016 - 2018 was $8.81 \%$. As a comparison, based on Mandiri Securities data, it is noted that corporate bond interest with AAA rating has a coupon rate of $7.98 \%$, which is greater than the average 5 years government bond (SUN) coupon rate of $6.71 \%$. Thus, the average profitability generated by largescale companies is slightly higher than the coupon rate of corporate and government bonds.

\subsection{Regression Analysis Results}

Multiple linear regression analysis is used to determine the magnitude of influence between the independent variables and the dependent variable. Regression equation 1 examines the effect of capital structure, managerial ownership, and firm size on profitability. While regression equation 2 examines the effect of capital structure, managerial ownership, firm size, and profitability on firm value. Regression results for equation 1 and regression equation 2 can be seen in Table 1 and Table 2 below.

Table 1 shows the results of regression equation 1, where the regression results show that capital structure has a positive effect on profitability at a significance level of $10 \%$, managerial ownership has a positive effect at a significance level of $5 \%$, and firm size has a positive effect at a significance level of $1 \%$. Thus, the increase in capital structure, managerial ownership, and firm size have a positive impact on increasing profitability.

Capital structure has a positive effect on profitability at a significance level of less than $10 \%$. This result shows that the use of debt has a positive impact on increasing profitability. The company can manage its debt well such that the revenue generated from the use of debt as a source of financing can cover its capital costs. The results of this study are in accordance with the study conducted by Lusy et al. (2018), but not in accordance with the study conducted by Manurung et al. (2014), Rizki et al. (2018), Alpi (2018), Hirdinis (2019), Nguyen et al. (2020), and Tahir et al. (2020).

Table 1: Regression Results from Regression Equation 1

\begin{tabular}{|c|c|c|c|c|c|}
\hline \multirow{2}{*}{ Model } & \multicolumn{2}{|c|}{ Unstandardized Coefficients } & \multirow{2}{*}{$\begin{array}{c}\begin{array}{c}\text { Standardized } \\
\text { Coefficients }\end{array} \\
\text { Beta } \\
\end{array}$} & \multirow{2}{*}{$\mathbf{t}$} & \multirow{2}{*}{ Sig. } \\
\hline & B & Std. Error & & & \\
\hline & & & & & \\
\hline CS & .017 & .010 & .128 & $1.697^{*}$ & .092 \\
\hline $\mathrm{MO}$ & .049 & .021 & .181 & $2.360^{* *}$ & .020 \\
\hline Size & .015 & .002 & .516 & $6.912^{* * *}$ & .000 \\
\hline $\begin{array}{l}\text { Cont. } \\
\mathrm{R}^{2}(\%) \\
\text { F-stat }\end{array}$ & -.146 & .033 & & $\begin{array}{c}-4.428 \\
26.5 \\
18.035^{\text {*** }}\end{array}$ & $\begin{array}{l}.000 \\
.000\end{array}$ \\
\hline
\end{tabular}

Table 2: Regression Results from Regression Equation 2

\begin{tabular}{|c|c|c|c|c|c|}
\hline \multirow{2}{*}{ Model } & \multicolumn{2}{|c|}{ Unstandardized Coefficients } & \multirow{2}{*}{$\begin{array}{c}\begin{array}{c}\text { Standardized } \\
\text { Coefficients }\end{array} \\
\text { Beta }\end{array}$} & \multirow{2}{*}{$\mathbf{t}$} & \multirow{2}{*}{ Sig. } \\
\hline & B & Std. Error & & & \\
\hline CS & -207 & .046 & -235 & $-4.525^{\star \star *}$ & 000 \\
\hline MO & -.409 & .200 & -.108 & $-2.043^{* *}$ & .043 \\
\hline Size & .056 & .021 & .145 & $2.712^{\star \star \star}$ & .008 \\
\hline Proft & 9.328 & 610 & .781 & $15.292^{* \star *}$ & .000 \\
\hline $\begin{array}{l}\text { Cont. } \\
\mathrm{R}^{2}(\%) \\
\text { F-stat }\end{array}$ & -.314 & .304 & & $\begin{array}{c}-1.035 \\
69.4 \\
71.881\end{array}$ & $\begin{array}{r}.303 \\
0.000\end{array}$ \\
\hline
\end{tabular}


Managerial ownership has a positive effect on profitability at a significance level of less than $5 \%$; thus managerial ownership affects increasing profitability. The involvement of managers as shareholders has an impact on improving performance, and managers work more productively to generate profits, so that profitability rises. The results of this study are not in accordance with the study conducted by Murni (2015) and Laila et al. (2017), who found a negative effect, as well as, the study conducted by Hossain (2016), who did not find any managerial ownership effect on profitability.

Firm size has a positive effect on profitability at a significance level of less than $1 \%$; hence, large scale companies generate higher profitability. Large-scale companies have greater opportunities to expand and develop their businesses, so it is natural for these companies to generate higher profits. The results of this study are consistent with the study conducted by Laksitaputri (2012), who found a positive effect of firm size on profitability. However, it is not in accordance with the study conducted by Murni (2015) and Laila et al. (2017) who found a negative effect, as well as, the study conducted by Hossain (2016) and Tahir (2020) who did not find the effect of firm size on profitability.

Table 2 shows the regression results of the regression equation 2 . The regression results show that capital structure has a negative effect on the value of the company at a significance level of less than $1 \%$; thus, the use of debt has an impact on the decline in firm value. The firm value is reflected in the stock market price, and the increasing use of debt has an impact on the decline in share prices, which is a phenomenon that occurs in manufacturing companies listed on the Indonesia Stock Exchange. The use of debt as a source of financing will increase the company's risk, namely the risk of bankruptcy. This risk causes investors to be less interested in investing in companies, so the response is negative and results in a decline in the share market price. Therefore, the increase in debt negatively impacts the value of the company. The results of this study are in accordance with the study conducted by Chen and Chen (2011), Murni (2015), and Manurung et al. (2014), but not in accordance with the study conducted by Charumathi and Khrisnan (2016), and Adenugba et al (2016), and Hirdinis (2019), who found a positive effect, and the study conducted by Fajri and Surjandari (2016), Hatane et al. (2018), and Purba and Africa (2019), who did not find any effect of capital structure on firm value.

Managerial ownership has a negative effect on firm value at a significance level of less than $5 \%$. Thus, the involvement of managers as part of shareholders directly cannot boost the increase in the company's share market prices, even the company's share price decreases instead. The results of this study are in accordance with the study conducted by Sulong et al. (2013), Murni (2015), and Indrarini et al. (2019), but not in accordance with the study conducted by Fajri and Surjandari (2016) and Purba and Africa (2019), who did not find any managerial ownership effect on firm value.

Firm size has a positive effect on firm value at a significance level of less than 1\%. Large-scale companies gain market confidence, so the market responds positively and have an impact on the company's share price. Investors are more confident to invest in large companies since there is a better guarantee for their investments. Because of this trust, investors are willing to buy the company shares at a higher price. The results of this study are consistent with the study conducted by Arifianto (2016) and Chabachib (2016), but not in accordance with the study conducted by Kumar and Singh (2013), which did not find any managerial ownership effect on firm value.

Profitability has a positive effect on firm value at a significance level of less than $1 \%$; hence, the higher the profitability the higher the firm value. The market responds positively where profitability is a representation of the firm's performance, such that investors are willing to buy the company shares at a higher price. Investors are interested in buying the company's shares with the expectation of high returns from such investments. The results of this study are in accordance with the study conducted by Gill and Obradovich (2012), Arifianto (2016), Chabachib (2016), Manurung et al. (2014), and Purba and Africa (2019), but not in accordance with the study conducted by Murni (2015), who found a negative effect, as well as, the study conducted by Fajri and Surjandari (2016) and Hatane et al. (2018), who did not find any effect of profitability on firm value.

\subsection{Discussions and Implications}

The purpose of this study is to examine the role of profitability as an intervening variable, which connects the capital structure, managerial ownership, and firm size with firm value. The results of the test with the Sobel test are as follows:

\subsubsection{Capital Structure - Profitability - Firm Value}

From the calculation of the Sobel test, we get a ' $z$ ' value of -1.59 . The $\mathrm{z}$ value obtained is less than 1.96 with a significance level of 5\%; therefore, profitability does not mediate the effect of capital structure on firm value.

\subsubsection{Managerial Ownership - Profitability - Firm Value}

The calculation result of the Sobel test shows a ' $z$ ' value of -1.54 . The ' $z$ ' value is less than 1.96 with a significance level of $5 \%$; therefore, profitability does not mediate the effect of managerial ownership on firm value. 


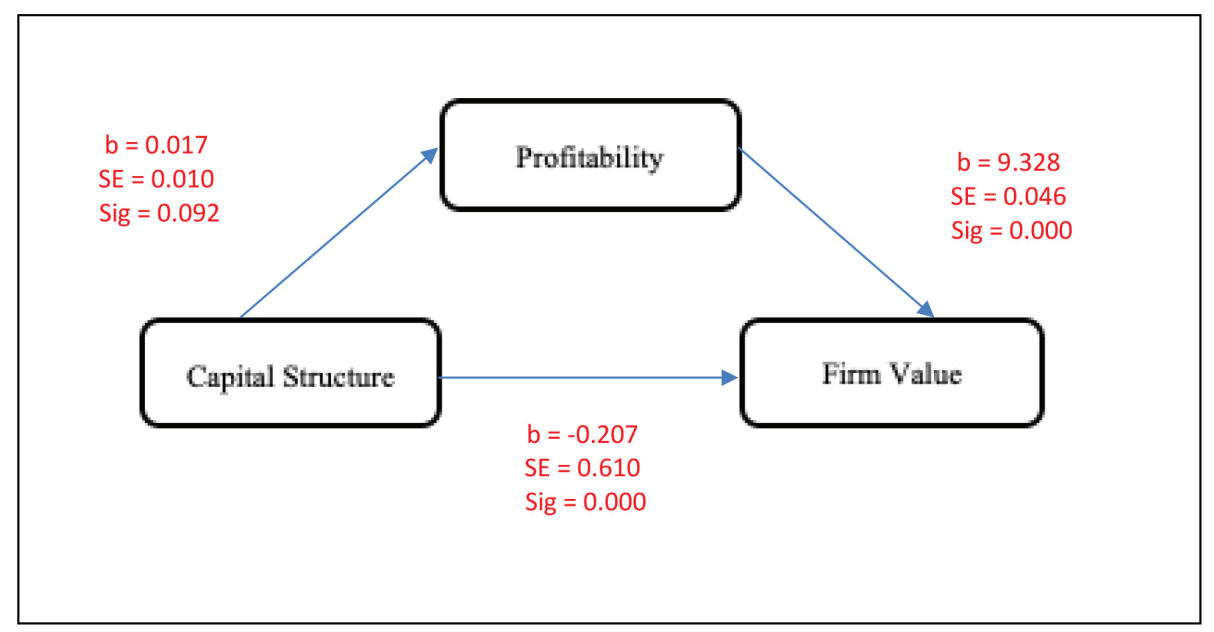

Figure 2: Capital Structure - Profitability - Firm Value

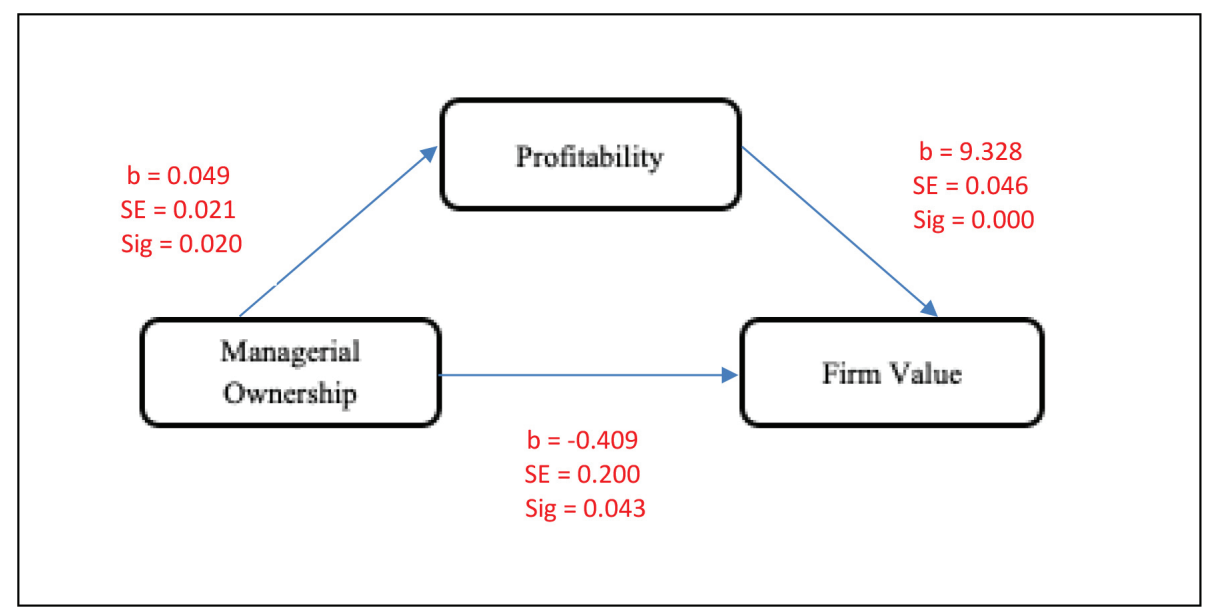

Figure 3: Managerial Ownership - Profitability - Firm Value

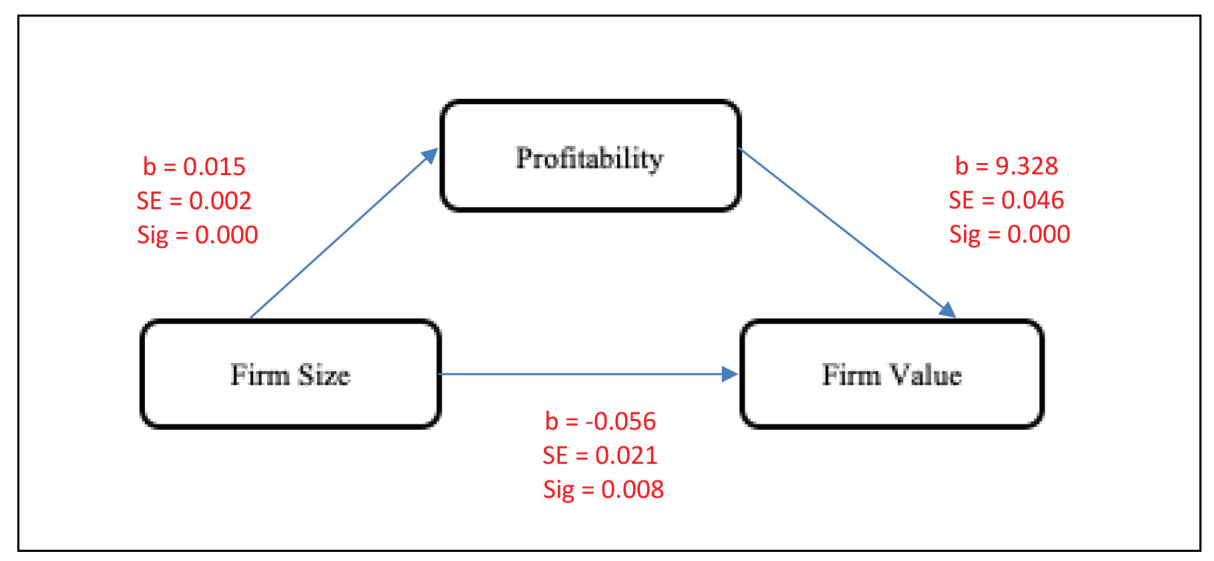

Figure 4: Firm Size - Profitability - Firm Value 


\subsubsection{Firm Size - Profitability - Firm Value}

The calculation result of the Sobel test shows that the $\mathrm{z}$ value is 2.44 , and the magnitude of $\mathrm{z}$ value greater than 1.96 with a significance level of $5 \%$, then profitability mediates the effect of firm size on firm value.

Based on the Sobel test of profitability as an intervening variable, profitability plays a role in mediating the effect of the firm size on firm value. So, the effect of firm size on firm value is indirect, but through profitability. While the capital structure and managerial ownership directly influence firm value.

Therefore, the market price of the shares of large-scale companies will increase if the resulting profitability is high.

As previously explained, this study examines the role of profitability as an intervening variable in mediating the effect of capital structure, managerial ownership, and firm size on firm value. Regression test results show that capital structure has a positive effect on profitability at a significance level of less than $10 \%$, and has a negative effect on firm value at a significance level of less than $1 \%$. Thus, the effect of capital structure on firm value is direct. When the management takes debt policy as a source of funding, the market would immediately respond negatively to it.

Other regression test results show that managerial ownership has a positive effect on profitability at a significance level of less than $5 \%$, and negatively affects the firm value at a significance level of less than 5\%. Therefore, the effect of managerial ownership on firm value can be direct or indirect. The management policy to own company shares to reduce agency costs has a positive impact on the company's performance; however, the market has responded negatively.

The results of the regression test of firm size on profitability and the firm value indicate that firm size has a positive effect at a significance level of less than $1 \%$. Thus, large-scale companies generate high profitability and the market responds positively. This is because large-scale companies have adequate capital to expand their business, and the market also responds positively since the investment security of investors is more secure than the investment security of investors in small-scale companies.

The Sobel test results indicate that profitability mediates the effect of firm size on firm value; therefore, profitability is proven to act as an intervening variable of firm size in influencing firm value. From the results of the Sobel test, profitability does not mediate the effect of capital structure and managerial ownership on firm value, because the effect of capital structure and managerial ownership is direct. Thus, not all variables used in the model are mediated by profitability in influencing firm value.

\section{Conclusions and Limitations}

The findings of this study contribute to agency theory, in which managerial ownership has an impact on increasing profitability, thereby reducing agency costs. Likewise, the findings of this study support the pecking order theory, where debt policy has an impact on decreasing firm value such that the use of internal sources of funds is a more appropriate policy to increase firm value. Besides, the results of this study also contribute by supporting signaling theory, where the market responds positively to the company's profitability and information is used by investors as a basis for making investment decisions.

Apart from the contribution of our research findings, the findings of our research also have certain limitations that can be overcome in future related studies. For example, the classification of manufacturing companies is done to be more specific, so that the results will be more accurate. Likewise, the proxy of the variable can be expanded; besides, macro variables must also be considered in subsequent research studies.

\section{References}

Adenugba, A. A., Ige, A.A., \& Kensiro, O.R. (2016). Financial leverage and firms' value: A study of the selected firm in Nigeria. European Journal of Research and Reflection in Management Sciences, 4(1), 14-32. http://www.idpublications. org/ejrrms-vol-4-no-1-2016/

Arifianto, M., \& Chabachib, M. (2016). Analysis of factors affecting firm value (a case study of companies listed on the LQ-45 Index for the 2011-2014 period). Diponegoro Journal of Management, 5(1), 1-12. https://ejournal3.undip.ac.id/index. $\mathrm{php} / \mathrm{djom} / \mathrm{article} / \mathrm{view} / 13485$

Brigham, E. F., \& Houston, J. F. (2015). Fundamentals of financial management (8th ed.). Boston, MA: Cengage Learning.

Charumanithi, B., \& Krishnan, M. (2016). On the determinants of the firm value of Indian companies. Global Business Review, 13(2), 251-267. https://doi,org/10.1177/097215091201300205.

Chen, L. J., \& Chen, S.Y. (2011). The influence of profitability on firm value with capital structure as the mediator and firm size and industry as moderators. Investment Management and Financial Innovations, 8(3), 120-129.

Dinh, H. T., \& Pham, C. D. (2020). The effect of capital structure on the financial performance of Vietnamese listing pharmaceutical enterprises. Journal of Asian Finance, Economics and Business, 7(9), 329-340. https://doi.org/10.13106/jafeb.2020. vol7.no9.329

Donaldson, G. (1961). Corporate debt capacity: A study of corporate debt policy and the determination of corporate debt capacity. Division of Research, Graduate School of Business Administration, Harvard University, Boston, Economics, 113, 387-432. https://economics.harvard.edu/people/people-type/ faculty.

Ehrhardt, M. C., \& Brigham, E. F. (2011). Financial management: Theory and practice (13th ed.). Boston, MA: Cengage Learning.

Gill, A., \& Obradovich, J. (2012). The impact of corporate governance and financial leverage on the value of American 
firms. International Research Journal of Finance and Economics, 91(2012), 47-56. https://digitalcommons.liberty. edu/busi_fac_pubs/25

Gitman, L. J. (2006). Principles of managerial finance (10th ed.). Boston, MA: Pearson Education.

Ghozali, I. (2016). Multivariete analysis application with IBM SPSS 23 Program. Issue 8, Prints VIII, BPFE. Universitas Diponegoro, Semarang, Indonesia. https://docplayer.info/57344301-Ghozaliimam-aplikasi-analisis-multivariate-dengan-program-spsssemarang-bpfe-universitas-diponegoro.html.

Hatane, S. E., Djajadi, A. T., \& Tarigan, J, (2018). The impact of corporate governance on intellectual capital and firm value: From Indonesia and Malaysia consumer goods. International Journal of Accounting, 4(1), 1-7. https://doi.org/0.5539/ijbm. $\mathrm{v} 11 \mathrm{n} 9 \mathrm{p} 218$

Hossain, M. I. (2016). Effects of capital structure and managerial ownership on profitability: Experience from Bangladesh. International Journal of Business and Management, 11(9), 218-229.

Jensen, M. C. (1986). Agency costs of free cash flow, corporate finance, and takeovers. The American Economic Review, 76(2), 323-329.

Jensen, M. C., \& Meckling, W. H. (1976). Theory of the firm: Managerial behavior, agency costs and ownership structure. Journal of Financial Economics, 3(4), 305-360. https://doi. org/10.1016/0304-405X(76)90026-X

Kumar, N., \& Singh, J. P. (2013). Effect of board size and promoter ownership on firm value: Some empirical fidings from India. International Journal of Corporate Governance, 13(1), 8898. https://doi.org/10.1108/14720701311302431

Laksitaputri, I. M. (2012). Analysis of factors affecting firm value with profitability as an intervening variable. Journal of Business Strategy, 5(1), 1-17. https://doi.org/10.24018/ ejbmr.2020.5.1.230

Lusy, Y., Hermanto, B., Panjaitan, T. W. S., \& Widyastuti, M. (2018). Effects of current ratio and debt-to-equity ratio on return on asset and return on equity. International Journal of Business and Management Invention, 7(12), 31-39.
Modigliani, F., \& Miller, M. H. (1963). Corporate income taxes and the cost of capital: A correction. The American Economic Review, 53(3), 433-443.

Myers, S. C., \& Majluf, N. S. (1984). Corporate financing and investment decisions when firm $\mathrm{s}$ have information that investors do not have. Journal of Financial Economics, 13(2). 187-221. https://doi.org/10.1016/0304-405X(84)90023-0

Nguyen, T. X. H., Pham, T. H, Dao, T. N, Nguyen, T.N., \& Tran, T. K. N. (2020). the impact of foreign ownership and management on firm performance in Vietnam. Journal of Asian Finance, Economics and Business, 7(9), 409-418. https://doi. org/10.13106/jafeb.2020.vo17.no9.409

Purba, J. T., \& Africa, L. A. (2019). The effect of capital structure, institutional ownership, managerial ownership, and profitability on company value in manufacturing companies. The Indonesian Accounting Review, 9(1), 27-38. https://doi.org/10.5430/ijfr. $\mathrm{v} 11 \mathrm{n} 4 \mathrm{p} 493$

Rizki, A., Lubis, A. F., \& Sadalia, I. (2018). The influence of capital structure to the firm value with profitability as intervening variables. The 2018 International Conference of Organizational Innovation, KnE Social Sciences, 220230. https://knepublishing.com/index.php/KnE-Social/issue/ view/123.

Ross, S. (1977). The determination of financial structure: The incentive signaling approach. Bell Journal of Economics, 8(1), 23-40.

Setiadharma, S., \& Machali, M. (2017). The effect of asset structure and firm size on firm value with capital structure as intervening variable. Journal of Business \& Financial Affairs, 6(4), 1-5. https://doi.org/ 10.4172/2167-0234.1000298

Sulong, Z., Hussin, A. H., Sanusi, Z. M., \& Jr, C. M. (2013). Managerial ownership, leverage, and audit quality impact on firm performance: Evidence from the Malaysian Ace Market. Accounting \& Taxation, 5(1), 59-70.

Tahir, S. H., Siddique, M. A. B., Syed, N., Rehman, F., \& Ullah, M. R. (2020). Mediating role of liquidity policy on the corporate governance-performance link: Evidence from Pakistan. Journal of Asian Finance, Economics and Business, 7(8), 15-23. https:// doi.org/10.13106/jafeb.2020.vol7.no8.015 